\title{
Internal Mechanisms of Governance and Risk Bearing of Banks: The Case of the CEMAC Zone
}

\author{
Etienne François Eloundou ${ }^{1} \&$ Doris Mireille Befen Djinja ${ }^{1}$ \\ ${ }^{1}$ Faculty of Economics and Applied Management (FSEGA), University of Douala, BP. 4032, Douala, Cameroon \\ Correspondence: Etienne François Eloundou, Faculty of Economics and Applied Management (FSEGA), University \\ of Douala, BP. 4032, Douala, Cameroon.
}

Received: September 14, 2016

doi:10.5430/ijfr.v7n5p190
Accepted: September 27, $2016 \quad$ Online Published: October 15, 2016

URL: http://dx.doi.org/10.5430/ijfr.v7n5p190

\begin{abstract}
This work tries to study the relationship between the internal mechanisms of governance and the bearing of financial risk by 20 banks in the CEMAC region during the period 2007-2013. The results suggest that a small size of the board of directors enables the exercise of managerial control, institutional and foreign directors do not have a significant impact on risk bearing contrary to theoretical predictions whereas public directors have a positive and significant impact on risk bearing. The size of the bank as well as it's capitalisation tend to reduce risk bearing translating an effect of accumulation of experience and diversification of activities as well as bank capitalisation. On the contrary ownership structure has no significant impact on risk taking.
\end{abstract}

Keywords: bank governance, governance mechanisms, board of directors, risk bearing

\section{Introduction}

Debates on the governance of firms began with the work of Berle and means in 1932. These authors found that during the development of quoted public limited companies, the ownership structure of large firms tends to disperse. In this structure, the decision power of shareholders (principal) diminishes and is attributed to the manager (agent) who does not have shares. This situation of separation of ownership and management is at the origin of the agency problem.

Manages who have as objective to manage the firm to serve the interests of the shareholders have specific competence and better information on the firm and its environment. This information asymmetry enables the managers to orientate the management of the firm according to their own personal interest which can be different from those of shareholders (Boubel and Pansard, 2004). Under these conditions corporate governance can be defined as a set of mechanisms that discipline managers.

In the case of banks risk is at the heart of banking activities since given their function of intermediation essential to the real sphere of the economy corrects information asymmetries between borrowers and investors, orientates savings towards investments. But paradoxically prudence does not always work, thus explaining the importance of prudential regulation. However there is an emerging consensus since the series of bank failures of the 1980s that credit risk remains the first internal cause of the bankruptcy of banks (Pantalone and Plat, 1987) for the United States; Von Westernhagen and al., (2004) for industrial countries, Bell and Pain (2000) for emerging countries, Vernier and Hodonou (2010) for African countries in ECOWAS (Note 1).

More precisely, excessive credit risk resulting from poor management of risk is the fundamental and internal determinant of bank failure. It corresponds to the incapacity of the borrower to pay interest due or to repay the principal in accordance with the terms specified in the credit convention (Greuning and Bratanovic, 2004). It is manifested by the importance of non-performing loan or doubtful receivables (Louzis and al., 2012).

The interest attached to bank failures is as a result of the high costs of these failures. These include financial losses for the shareholders, the depositors and the assurer of deposits. This equally involves the destabilisation of the financial system as a result of bank failure, if several individual bankruptcies degenerate into a bank crisis by contagion. The resolution of such a bankruptcy leads to the wastage of resources.

The management of risk corresponds to a set of decisions that enable the amelioration of the profitability-risk profile and enable the bank to control its risks and reduce the risk of bank failure. 
Excess risk can be defined as the result of a credit decision that leads to a defaults risk of the institution that is considered to be acceptable by different partners of the bank namely the shareholders and the regulators (Godlewski, 2005). The main cause of this phenomenon is that the agents at the origin of the risk do not bear all the risk of their decision. This definition places the problem of risk in the framework of bank governance whose mechanisms enable a better control of risk management.

The CEMAC (Note 2) zone is not excluded. In fact this zone recently had a bank crisis whose intensity required the sector to be restructured twice to clean the banking system. It should be highlighted that the particularity of the banking system of the countries of CEMAC, at the end of the 1980s was the strong presence of the government in several aspects of its organisation and especially its functioning (Avom, 2007).

In fact, following the European model and in particular that of the French banks remained under the influence of the state who wanted to use as a powerful instrument of economic development so as to compensate for the loss of control over monetary policy and especially exchange policy. Among the internal factors of the bank crisis was the presence of the state as a shareholder in these banks which favoured the development of conflicts of interest and opacity in management by developing an opportunistic behaviour in the form of moral hazard of the type described by Stiglitz and Weiss (1981), this was materialised in the form of several public and private bank debts with implicit collaterals from the state and/or those of debtors who were top government officials. According to Hugon (2007), the factors that lead to the deterioration of banks were linked to the quality of management of these banks; management errors are of two types namely the distribution of credits to unprofitable companies and the excessive inflation of general expenses. Today the situation of the banking system seems to be good which leads to the question; what is the impact of internal governance mechanism of banks on risk bearing?

The studies on the composition of the board of directors and its impact on the risk of banks in the CEMAC region are almost inexistent, that is why the objective of this article is to analyse the efficiency of the board of directors as well as its relationship with risk bearing by banks. The rest of the article is structured into three parts which will enables us to position the research with respect to previous findings (section 2). The details of the model are presented in section 3 and the results as well as the recommendations in section 4.

\section{Literature Review, Theory and Development of Hypothesis}

It is commonly admitted that the capacity of the board of directors to align its interests with those of the shareholders depend on its composition and its size, Fama and Jensen (1983). In fact, these authors show that the quality of the board of directors enable to minimise agency costs and maximise the value of the firm. Several aspects were developed in literature and they suggest that the independence as well as its size is supposed to increase the efficiency of the board of directors. However, John and Senbet (1998) highlight that the efficiency of the board can equally be affected by a third characteristic: its internal administrative structure (Note 3 ).

In conformity to the agency theory, the large size of the board of directors favours its domination by the managers and eventually creates conflicts of interest between the directors and the managers. This leads to a board that is fragmented, inefficient and having difficulties to arrive at a consensus on important decisions, (Jensen, 1993).

The agency theory states that the internal directors of the bank can hardly oppose the decision taken by the managers of the bank because these later are their superiors and consequently have the authority to compromise their career and their future in the company.

Moreover, external directors of the firm namely foreign and institutional directors can oppose the decisions of managers since they represent influential partners of the bank because of their important financial means enabling them to become active investors in the control of managers (Whidbee, 1997 and Aggarwal and Jacques, 1998).

Their representatives in the board of directors can influence the decisions of the directors with the aim of maximising the returns of their investments and consequently improve the value of the bank. They equally have privileged access to information because of their activities and several investments that they realise. This implies a good knowledge of the sector, abundant information on the environment and consequently a better appreciation of the performance of managers (Alexandre and Paquerot, 2000). In addition, these directors and their institutions show prove of greater capacity in the treatment of financial and economic information. In fact, they benefit from particular competence enabling them to analyse the accounts of the bank, its perspectives of development as well as the quality of its management.

Nevertheless, Paquerot (1997) reveal that the agency theory is not enough to explain the actions of the institutional directors on the mangers, the theory of entrenchment will have to be taken into consideration which says that institutional directors are not incited to reinforce their control because of the strategies of the managers who can try 
to increase their influence on the partners 9natably through information asymmetry). On the other hand, they do not have the possibility to replace managers when these later eliminate competition on the labour market.

On the other hand, the thesis of myopic behaviour of institutional directors advanced by Drucker (1986) and Graves (1988) stipulates that when managers take decisions they react on organisational and ownership pressure thus leading to risk aversion and a sacrifice of long term profitability such as research and development investments to limit the risk of taking over control. According to Porter (1992), institutional investors do not have access to specific information and they have difficulties in evaluating the firm in the long run. As such they will concentrate on performance measures such as accounting or stock profitability. They do not give the managers the possibility to put in efforts in the search of new investment opportunities.

According to the thesis of institutional activism, institutional directors can make managers to concentrate on long term profitability, by also increasing risk (Bushee, 1998); Wahal and Mc Connell (2000). The basic argument of this thesis is that the institutional shareholders can have an information advantage with respect to other shareholders. With respect to individual shareholders, institutional shareholders are more solid and resistant to the performance judgement of managers. Thus, they incite the managers to put in place long term investment projects that increase the competitively of firms.

Based on the affirmations of the agency theory, banks belonging to the state would face less financial market indiscipline. In economic literature based on the argument of social well-being, the main raison of public banks would be the existence of insufficiencies on the financial mark and the credit market (Stiglitz and Weiss, 1981). Therefore the creation of public banks would respond according to this argument to the fact that private banks do not take into consideration social returns in their financing decisions of projects. Moreover, the theory of property rights and that of public choice are two complementary approaches which enable to analyse the deviations in performance between the public company and the private company. According to Ehrlicht and al., (1990) from these two theories one can some fundamental propositions which justify the quality of assets of public banks with respect to private banks: politicians do not work for general interest and are focused on their personal interest the search of power is their main preoccupation and they hardly face all the monetary and financial consequences of their decisions.

\subsection{The Impact of the Ownership Structure on Risk Bearing}

If the first studies that examined the relationship between ownership structure and risk bearing were carried out by Berle and Means (1932), they were formalised by Jensen and Meckling (1976), then by Demsetz (1983). However, the relationship between risk bearing and ownership structure is complex since the results sensitive to the period, the nature of the measure of risk, the nature of the relationship and the sample chosen (Thierno, 2007)

The nature of shareholders can influence the performance of the firm, and consequently its risk bearing given that one of the objectives of the bank is to maximise its performance at a given risk level. In fact, the shareholders constitute a heterogeneous population. The objectives and horizons of an investor can vary according to whether it is the shareholder manager, family, industrial or the state. Several works have studied the relationship between the nature of shareholders and risk bearing in banks to the state mainly but also in other contexts more recently. Sironi and al. (2006) examined the relationship between risk bearing and the shareholder structure in Europe from 1999 to 2004. They use four variables of shareholder structure and three measures of risk with two from market data. The variables of shareholder structure are the traditional ones namely the private cooperative bank, public bank and concentrated bank. The results show that the level of concentration is associated to a better quality of the loans, a low asset risk and low insolvency risk. In addition, the variable foreign bank is negatively correlated with the risk of insolvency which signifies that foreign banks have the tendency to take less risk than local banks. These results are shared by Bonin and al. (2005); Micco and al. (2007) and Iannota and al. (2007).

If one of the limits of the previous studies is based on the analysis of the relation between risk bearing and shareholder structure considers only one of the dimensions of the geography of capital, our study is different from the others because it takes into consideration the specific nature of bank ownership in the CEMAC region namely the percentage of capital held by the state, the private nationals and foreigners instead of a dichotomous variable that materialises the typology of the bank.

\section{H1: The nature of ownership influences risk bearing.}

\subsection{The Impact of the Size of the Board of Directors on Risk Bearing by Banks}

In conformity to the agency theory, the large size of the board of directors favours its domination by the managers and creates a conflict of interest between the directors and the mangers, leading to a fragmented and inefficient board which makes it difficult to obtain a consensus on important decisions consequently high risk bearing (Jensen, 1993). 
Some authors have also concluded that the size of the board of directors is positively linked to the performance of firms as well as to risk bearing (Adams and Mehran, 2003). On the contrary, several other have insisted on the positive effect of a large size (Dalton and al, 1999). According to them, the additional capacity of larger boards can be more important than the increase in problems of communication, coordination and decision making. Blanchard and Dionne (2004) suggested that the higher the number of directors the more likely will sophisticated instruments be used to hedge against risk thus justifying the excessive risk bearing of managers.

We foresee that a large board of directors will produce multiple competences that will be beneficial for management and the value of the banks. That why we anticipate the following hypothesis:

\section{H2: The size of the board of directors has a negative impact on the risk bearing of banks in CEMAC}

\subsection{The Impact of Foreign Directors on the Risk Bearing of Banks}

Studies on the governance of banks by foreigners (such as Berger and al, 2000; Claessens and al, 2001) usually identify differences in efficiency between bank institutions with high foreign ownership and those with high local private ownership. In fact, the first banks are usually part of a holding bank and benefit from economies of scale that is a characteristic of large organisations. They also have the advantage of serving multinational customers by settling in other countries (Saunders and al., 1990). In addition, banks with high foreign ownership benefit from a better access to the capital market, a higher capacity to diversify risk and greater opportunities to offer some of their services to foreign customers difficult to conquer. In developing countries, banks with foreign ownership coming from developed countries equally have access to new technology especially information technology.

Demirgüc-kunt and Huizinga (2004) add that these banks are except from many restrictions in the allocation of credits. Bonin and al. (2005) affirm that in developing countries and especially those in transition, the exposure of banks to foreign capital in emergent countries improves their performance by offering them greater access to technology and especially to better governance practices. In addition, the foreign director improves the independence of the board of directors through a better credit policy. That is why in the CEMAC region we anticipate the following hypothesis:

\section{H3: Foreign directors have a positive impact on the risk bearing of banks}

\subsection{The Impact of Institutional Directors on Risk Bearing of Banks}

Institutional investors (financial and others) are supposed to play an active role in the governance of banks. These particular shareholders represent influential partners of the bank because of their important financial means (Whidbee, 1997 and Agrawal et Jacques, 1998) their presence in the board of directors enables greater control efficiency.

Mamoghli and Dhouibi (2009) equally support the fact that institutional investors have a better expertise in the domain of risk bearing which could incite managers to select the best investment projects. In fact, they conclude that the presence of institutional directors in Tunisian banks is associated to lower risk of insolvency.

In fact, the impact of institutional directors and investors that they represent in the board on the value of the bank and the firm in general has been debated in literature between positive (such as that of Mc Connell and Servaes, 1995 and Whidbee, 1997) and negative (such as that of Morck, Shleifer and Vishny,1988; Shleifer and Vishny, 1997). This shows that their impact on risk bearing is uncertain.

By taking into account these results we anticipate the following relationship in the CEMAC context:

\section{H4; Institutional directors have a negative impact on the risk bearing of banks in the CEMAC zone}

\subsection{The Impact of Public Directors on Risk Bearing}

Economic literature also justifies the existence of public banks by the political function that the later can play. In fact, these arguments suppose that the objective of the government to stick to power dominates the noble objective of maximising social well-being (Shleifer, 1998). The direct implication of this political argument is that government banks would be inefficient given that they are used by politicians in power to transfer financial resources to their partisans. This would equally be true in countries where judicial and legislative powers are not totally independent. In effect, Dinç (2005) shows empirically that banks with government capital increase their credit with respect to private banks during election years. In the CEMAC context characterised by a high level of privatisation of banks due to the recent crisis in the banking sector and a weak judicial protection, we anticipate the following relationship:

\section{H5: Public directors have a positive impact on the risk bearing of banks in the CEMAC region}




\section{Methodology}

The data used in this paper are from a secondary source. They are from the database of the International Monetary Fund (IMF, World Development Indicators, 2015). This data is quantitative in nature and since it is longitudinal we will use panels just as most previous studies based on this problem.

\subsection{The Composition of the Sample}

Our work will be limited to commercial banks in the CEMAC region from 2007 to 2013 from reports published by COBAC (Note 4). The choice of the period is justified by the end of the second set of bank restructuring by COBAC in 2006 and the availability of data. Our work is based on double dimension panels and we would be interested in banks in countries in the CEMAC region which are under the same regulation namely, Cameroon, Chad, the Central African Republic, Gabon, Congo and Equatorial Guinea. However, we exclude from our sample banks with incomplete or unavailable data. Our sample is finally made up of 20 banks whose choice of variables was guided by recent studies on bank governance (Vernier and Hodonou, 2010; Bassem and al., 2012) but our study is different in certain aspects'; the sample is larger. The absence of dual managerial functions and the period is more recent. The equation of our model is written as follows:

$$
\prod_{i, t}=C+\sum_{k=1}^{k=k} \alpha_{k} X_{i, t}^{k}+\varepsilon_{i, t}
$$

With:

\section{$\prod_{i, t}$ The measure of bank risk i at time $\mathrm{t}$}

$\prod_{1}$

Corresponds to the two measures of financial risk of banks namely credit risk (R_CRED) and the risk of insolvency (R_Faill); $\mathbf{C}$ is the constant term; $\boldsymbol{\varepsilon}_{\mathbf{i}, \mathbf{t}}$ is a random perturbation whose form is generated by an autoregressive process of order 1.

$\mathrm{X}_{\mathrm{i}, \mathrm{t}}$ represents the group of explanatory and control variables of the model.

Thus the equation becomes:

$$
\begin{array}{r}
\Pi_{\mathrm{i}, \mathrm{t}}=\mathrm{C}+\alpha_{1} \mathrm{CAP}+\alpha_{2} \text { TAILLE }+\alpha_{3} \text { ADINST }+\alpha_{4} \text { TAICA }+\alpha_{5} \text { ADPUB }+\alpha_{6} \text { ADETR }+\alpha_{7} \text { ETAT }+\alpha_{8} \text { ETRA }+\alpha_{9} \\
\text { PRIVENAT }+\varepsilon_{\mathrm{i}, \mathrm{t}}
\end{array}
$$

\subsection{Definition and Measure of Variables of the Study}

It involves defining the explanatory and independent variables as well as the control variables.

\subsubsection{The Independents Variables (Credit Risk and Risk of Accounting Failure)}

In conformity to the context of CEMAC, only two financial (Note 5) risks mostly born y banks in the CEMAC region will retain our attention in this study: the risk of insolvency (Note 6) and credit risk. Several authors suggest that one of the indicators of the stability of a bank is the index of its risk of insolvency (Mc Allister and Mc Manus, 1993; Vernier and Hodonou, 2010).

This indicator is:

Risk of insolvency or accounting failure $\left(\mathbf{R} \_\right.$Faill $)=\frac{[E(R O A)+C A P]}{\sigma(R O A)}$

The numerator represents the sum of the mean of the ratio of economic profitability and the capital/asset ratio in the formulae above. The denominator represents the standard deviation of the value of economic profitability (ROA) of the assets of the bank. This formula shows on one hand that if the return on assets increases, then the index of risk of insolvency reduces.

Credit risk can be measured by different financial ratios. The ratio outstanding doubtful credits/total credit (net) represents a measure of the quality of the credit portfolio. A high value of this ratio indicates a degrading banking activity of poor quality and implies a higher risk of default for banks. 
Another ratio is the share that the reserve for credit risk represents in total credits. A high value of this ratio indicates anticipated important losses in the credit portfolio. Moreover, this ratio can equally be interpreted as a measure of "security mattress " aimed at absorbing future losses.

But that retained by COBAC to measure credit risk is;

$$
\text { Credit Risk }\left(\mathbf{R} \_ \text {CRED }\right)=\frac{\text { Doubtfull credit }}{\text { Total credit }}
$$

\subsubsection{Explanatory Variables}

\section{The Size of the board of directors}

The size of the board of directors is measured by the number of directors who seat in the board of directors. This variable is used by Jensen (1993), Adams and Mehran (2003) and many others.

\section{Institutional Directors}

The study of the relationship between the percentage of institutional directors seating in the board and bank profitability is justified by the fact that these later are qualified by Jensen (1993); Adams and Mehran (2008) as having great expertise. This variable is measured by the percentage of institutional directors/ the total number of directors.

\section{Foreign directors}

The proportion of foreign directors seating in the board has been used by several authors such as Claessens (2001); Domanski (2005). As concerns the role played by foreign directors in the management of credit risk, the theoretical debate is still open. It is measured by the number of independent directors /total number of directors.

\section{Public Directors}

As Berger and al. (2005), we introduce the variable pubic directors to measure the impact of the presence of a director representing the government on the profitability of banks in the CEMAC region. This variable is defined as the proportion of state directors seating in the board.

\section{The percentage of Capital retained by the state}

In sub-Saharan Africa public banks have the reputation of maximising several objectives with some which cannot be measured and can weaken the incentives of managers (Vernier and Hodonou, 2010). The variable ETAT measures the amount of capital belonging to the state/the capital of the bank.

\section{The percentage of Capital held by Foreigners}

This variable measured the percentage of capital held by foreign investors. In Europe the study of Sironi and al. (2006) shows that the variable foreign bank is negatively correlated with the risk of insolvency, which signifies that foreign banks have the tendency of bearing more risk than domestic banks.

\section{The percentage of Capital held by Private nationals}

This variable measures the percentage of capital held by private nationals. Using a sample of banks operating in 133 countries all over the world, Marco and Fernandez (2007) indicate that the risk profile of local private banks is significantly lower than that of foreign banks.

\subsubsection{Control Variables}

We have been able to determine from literature two variables which affect credit risk and risk of the bankruptcy: the size of the bank and the level of bank capitalisation. Previous empirical studies give the useful clues to anticipate the expected sign of this variable.

\section{The size of the bank and Financial Risk}

Theoretical arguments pioneering the relationship between the size of the bank and risk can be divided into two categories which are not exclusive. On the other hand arguments in favour of a negative relationship between size and performance and on the other hand arguments in favour of a positive relationship. Several authors found a positive relationship between risk bearing and the size of the firm (Ceboyan and al., 1999); on the others a positive relationship (Vernier and Hodonou, 2010). It is measured by the neperian logarithm of the total assets of the bank. SIZE $=$ Ln (Total Assets) 


\section{The capital level of the banks and financial risk}

The relationship between the level of capital and performance was highlighted for the first time by Shrieves and Dahl (1992) to measure the impact of the level of capital on financial profitability. This is measure using the ratio:

$$
\mathrm{CAP}=\frac{\text { Capital }}{\text { Total Assets }}
$$

Table 1. Governance variables of the study

\begin{tabular}{|c|c|c|c|c|}
\hline \multicolumn{2}{|c|}{ Variables } & Definition & Measures & Sources \\
\hline \multirow[t]{3}{*}{$\begin{array}{l}\text { Ownership } \\
\text { structure }\end{array}$} & Privenat & $\begin{array}{l}\text { Percentage of } \\
\text { bank's capital held } \\
\text { by private nationals }\end{array}$ & $\begin{array}{l}\text { Amount of capital held by } \\
\text { private nationals/ Capital of } \\
\text { the banks }\end{array}$ & \multirow{3}{*}{$\begin{array}{l}\text { Sironi and al. } \\
\text { (2006); Marco and } \\
\text { Fernandez (2007); } \\
\text { Vernier and } \\
\text { Hodonou (2010) }\end{array}$} \\
\hline & Etat & $\begin{array}{l}\text { Percentage of } \\
\text { capital of the bank } \\
\text { held by the state }\end{array}$ & $\begin{array}{l}\text { Amount of capital held by } \\
\text { the state / Capital of the bank }\end{array}$ & \\
\hline & Etra & $\begin{array}{l}\text { percentage of } \\
\text { capital held by } \\
\text { foreigners }\end{array}$ & $\begin{array}{l}\text { Amount of capital held by } \\
\text { foreigners }\end{array}$ & \\
\hline \multirow[t]{4}{*}{ Board of directors } & Taica & $\begin{array}{l}\text { Size of the board of } \\
\text { directors }\end{array}$ & Total number of directors & $\begin{array}{l}\text { Adams and Mehran } \\
(2003 ; 2008)\end{array}$ \\
\hline & Adinst & $\begin{array}{l}\text { Proportion of } \\
\text { institutional } \\
\text { directors }\end{array}$ & $\begin{array}{l}\text { Number of institutional } \\
\text { directors/ Total number of } \\
\text { directors }\end{array}$ & $\begin{array}{l}\text { Jensen (1993), } \\
\text { Ghazi (2006) }\end{array}$ \\
\hline & Adetr & $\begin{array}{l}\text { Proportion of } \\
\text { foreign directors }\end{array}$ & $\begin{array}{l}\text { Number of foreign } \\
\text { director/Total number of } \\
\text { directors }\end{array}$ & $\begin{array}{l}\text { Claessens (2001), } \\
\text { Domanski (2005) }\end{array}$ \\
\hline & Adpub & $\begin{array}{l}\text { Proportion of public } \\
\text { directors }\end{array}$ & $\begin{array}{l}\text { Number of public } \\
\text { directors/Total number of } \\
\text { directors }\end{array}$ & $\begin{array}{l}\text { Berger and al. } \\
\text { (2005), etc. }\end{array}$ \\
\hline
\end{tabular}

Source: The authors.

\subsubsection{Descriptive Statistics of the Variables of the Model}

Table 2 below represents certain descriptive variables of the sample, the Remarque that can be made is that average credit risk of banks of the CEMAC region is $11.9 \%$, it can be low compared to countries such as Tunisia where it is $19.7 \%$. But it is high with respect to some countries like France (3.88\%).

The risk of bank failure is therefore the highest risk of banks in the CEMAC region with an average of $38.62 \%$, it is close to that of countries of ECOWAS, even though it is higher (35.55\%) (Note 7). The mean of the return on assets (ROA) during the period of the study is at an average of $1.9 \%$ whereas the mean of the return on equity (ROE) is $21.48 \%$.

The average size of banks in the sample is $279,034,864.3$ in thousands of Francs CFA. These banks could be considered as small banks in comparison to European banks and others. We can take the example of the first 10 European banks which represent 1500 billion Euros that is $122 \%$ of the GDP of their countries (Note 8).

Table 2 shows that the mean size of the board of directors is 13 members, the average is made of 7 members, foreign directors represent the highest proportion of directors with sometimes 5 members, public directors represent the lowest $(0,428)$ proportion and institutional directors constitute the intermediary proportion $(0.8571)$. Moreover, there is a net disparity in the mean values of the explanatory and independent variables and their standard deviations between the different banks of the sample. This seems to indicate that the structure of our sample is heterogeneous and that complementary specification tests are indispensible in choosing the appropriate estimator. 
Table 2. Descriptive statistic of variables studied

\begin{tabular}{r|rrrrr} 
Variable & Obs & Mean & Std. Dev. & Min & Max \\
\hline r_cred & 140 & .11901 & .3824124 & 0 & 4.310162 \\
r_faill & 140 & .3862032 & 1.808221 & .0093604 & 21.10013 \\
tail & 140 & 12.15378 & 1.012971 & 9.882622 & 13.95558 \\
\hline cap & 140 & .0845377 & .0370656 & .014317 & .2117273 \\
taica & 140 & 7.107143 & 2.355757 & 2 & 13 \\
adetr & 140 & .4316066 & .4118821 & .14285 & 5 \\
\hline adinst & 140 & .360836 & .2198332 & .02 & .8571 \\
adpub & 140 & .1369285 & .1117983 & 0 & .42857 \\
privenat & 140 & 18.114 & 17.77424 & 0 & 80.67 \\
\hline etra & 140 & 69.3955 & 18.367 & 19.33 & 99.99 \\
eta & 140 & 10.3905 & 11.90006 & 0 & 49
\end{tabular}

Source: Estimations of authors on STATA 12.00

\subsection{Economic Specification of the Model}

This involves the study of the effects of internal mechanisms of governance on risk bearing in the bas of the CEMAC region using a multiple regression model. The economic specification enables us to test the hypothesis that the constant term is the same for all banks or it is specific for all banks and to verify the homogeneity of the model.

\subsubsection{Specification Test of Individual Effects}

In order to validate our theoretical model, we need to carry out two types of tests: Fischer's test (F-test) that verifies the presence of individual effects. Haussmann's test (1978) that verifies the nature of these effects (fixed individual effect or random individual effect).

Our work consists of testing the hypothesis that the constant is common to all banks. If this hypothesis is rejected, we will obtain an individual effect model. In this case, the process of data generation cannot be considered as homogenous and this process is the same for all banks. In such a case the technique of panel data cannot be justified. Apart from these two cases, the source of heterogeneity has to be determined so as to better specify the model (Bourbonnais, 2011).

The null hypothesis of this test is as follows; $\mathrm{H}_{0}: \beta_{1}=\beta_{2}=\beta_{\mathrm{i}}=0$. This hypothesis assumes the existence of specific effects unique for each individual, in this particular case, the bank. If we accept the null hypothesis, we conclude that there exist a theoretical model for each bank and no individual effect exists. The model is therefore totally homogenous. Moreover, the rejection of $\mathrm{H}_{0}$ would lead to the conclusion that there exists a specific individual effect and thus conclude that the model is heterogeneous.

Thus we will use Fischer's statistic to $(\mathrm{K}+1)(\mathrm{N}-1)$ and $\mathrm{NT}-\mathrm{N}(\mathrm{K}+1)$ degree of freedom. Ficsher's statistic can be written as follows:

$$
\mathrm{F}=\frac{\left(S C R_{c}-S C R_{m c} / N-1\right.}{S C R_{m c} / N(T-1)-K}
$$

$\mathrm{SCR}_{\mathrm{c}}$ is the sum of the squares of the residue of the model, and $\mathrm{SCR}_{\mathrm{mc}}$ is the sum of the residues of the fixed effect.

- If $\mathrm{Fc}<$ Fstat we accept $\mathrm{H}_{0}$

- If $\mathrm{Fc}>$ Fstat we reject $\mathrm{H}_{0}$ 


\subsubsection{Application of Different Test to the Banks of the CEMAC Region}

In order to test the hypothesis constructed using a regression model of the internal mechanisms of the banks and their impact on risk bearing in the CEMAC region, the test of homogeneity of panel would be carried out using Hsiao's test (1986). The F statistic of Hsian follows a Fischer distribution to $(\mathrm{K}+1)(\mathrm{N}-\mathrm{N}-1)$ and $\mathrm{NT}-\mathrm{N}(\mathrm{K}+1)$ degree of freedom can be written as follows:

$\mathrm{F}=\frac{\left(S C R_{b}-S C R_{a}\right)-(N-1)(K+1)}{S C R_{a} / N T-N(K+1)}$

With:

$\mathrm{SCR}_{\mathrm{a}}$ : the sum of the squares of residues without fixed effect

$\mathrm{SCR}_{\mathrm{b}}$ : the sum of squares of residues with individual effect

$\mathrm{N}$ : the number of banks, which is 20 in this case

$\mathrm{T}$ : the number of years; $\mathrm{T}=7$ years

$\mathrm{K}$ : the number of explanatory variables; $\mathrm{K}=7$

The Hausman's test is a specification test that enables to determine if the coefficients of the two estimations (fixed and random) are statistically different.

The result of Hsiao's test enables us to conclude that the model is heterogeneous and the result of Hausman's test indicates that the model that adapts best to the structure of our sample is the fixed effect model.

\subsection{Presentation of Results}

In the two models studied, the size of the banks is negatively related to risk bearing but this relationship is significant only at $10 \%$ with the risk of accounting failure. It could be deduced from this result that the larger the size of the bank the lesser the financial risk it bears. The result that is well known in financial literature is that of the doctrine of « too big to fail » which argues that the larger the size of the bank the lesser the risk of financial failure (Godlewski, 2005), the large size of the bank enables it to carry out diversification strategies to improve the quality of the portfolio of its assets.

Another result is that of foreign directors just like institutional directors they do not have any impact on risk bearing. This counter intuitive result suggests that foreign and institutional directors are not efficient in the control of managers. This does not permit us to validate the third and fourth hypothesis. Thus, external directors in the CEMAC region are not efficient in the control of managers. According to the conclusions of Adams and Mehran (2008) these directors are not able to understand the complex nature of each bank, solve internal agency problems and accomplish their main role which is disciplining the managers especially on risk bearing.

On the contrary, public directors have a positive relationship with risk bearing. This relation is significant at 5\% whatever the explanatory variable of risk used, which can be explained by a less prudent credit policy (Boussada, 2012). This result is in conformity to our forecasts and literature thus validating our fifth hypothesis. It also enables to confront the theoretical policy that argues that the management of banks in the CEMAC region is carried out in a customised and political way. Just as in the Tunisian banking context, credit is used by those in authority to put pressure and orientate activities of economic agents politically Hibou (2008). In such a context, credits are granted not on the basis of strict criteria but on criteria of political allegiance and personal relationships without any serious guarantee.

It appears in our results that the size of the board of directors is positively related to risk bearing of banks even though this relationship appears significant only with credit risk at 10\%. This result is in contradiction to the study of Hermalin and Weisbach (2003) and Adams and Mehran (2003) who support a board of directors of large size. This result is in line with that of Jensen (1993) who proposes that a board of directors with a small number of directors produces a control mechanism that is more efficient just as Vernier and Hodonou (2010). This result enables to confirm our second hypothesis.

Bank capitalisation is negatively related to risk bearing of banks in the CEMAC zone, it is the highest coefficient of the explanatory variables in the two models studied but much higher in the risk of accounting failure model and also the most significant (5\%) and (10\%) in the model with credit risk. We can say that bank capitalisation constitutes the explanatory variable that is most pertinent in the explanation of risk bearing among the variables of the study. It 
enables to understand the measure of the valorisation of social capital of banks by COBAC just as one of the objectives of constituting a security mattress to absorb eventual shocks relative to the activity of financial intermediation.

Finally, variables which materialise the ownership structure have no effect on risk bearing of banks. Thus, the proportion of capital held by the state, foreign private and nationals has no influence on credit risk and accounting failure risk.

Table 3. Internal mechanisms of governance and risk bearing by banks in the CEMAC zone

\begin{tabular}{lll} 
Variables & R_CRED & R_FAILL \\
C & 1.714837 & 6.04185 \\
& $(0.08)$ & $(1.94)$ \\
\hline TAILLE & -0.0029676 & $-* 0.3188532$ \\
& $(-0,09)$ & $(-1,81)$ \\
\hline CAP & $*-1.954764$ & $* *-9.673629$ \\
& $(-1.68)$ & $(-2.44)$ \\
\hline TAICA & $* 0.0313168$ & 0.0565596 \\
& $(1.82)$ & $(0.70)$ \\
\hline ADETR & -0.0616369 & 0.0284705 \\
& $(-0.55)$ & $(0.26)$ \\
\hline ADINST & 0.2268286 & 0.706882 \\
& $(1.13)$ & $(0.87)$ \\
\hline ADPUB & $* * 1.18077$ & $* * 2.768119$ \\
& $(2.90)$ & $(1.25)$ \\
\hline PRIVENAT & -0.003024 & -0.0292114 \\
& $(-0.04)$ & $(-0.75)$ \\
\hline ETAT & -0.083058 & -0.0561701 \\
& $(-1.33)$ & $(-1.58)$ \\
\hline ETRA & -0.008478 & 0.0253821 \\
& $(-0.22)$ & $(1.35)$ \\
\hline Prob $>$ F & 0.0000 & 0.0019 \\
\hline R $^{2}$ & 0,487473 & 0,58745 \\
\hline R $^{2}$ Ajusté & 0,463921 & 0,52682 \\
\hline Observations & 140 & 140 \\
\hline
\end{tabular}

Remark: the value in the brackets is the value $\mathrm{T}$ of student. *,**, ***: coefficients that are significantly different from zero, respectively at $10 \%, 5 \%$ and $1 \%$.

\section{Conclusion}

The objective of this article was to study the relationship between internal mechanisms of governance and risk bearing of banks in the CEMAC zone notably credit and bankruptcy risk. In order to succeed in our research we have used a tripartite process which involves the presentation of the context of the research, carry out a theoretical and empirical literature review that enabled us to formulate the hypothesis. Then, we proceeded from a panel of 20 banks of the CEMAC region from 2007 to 2013.

Finally, from our results we find that public directors have a positive and significant impact on the two types of risk studied in the CEMAC region as well as the size of the board of directors that significantly affects credit risk of banks in the region. However, institutional and foreign directors do not influence risk bearing as well as the shareholding structure materialised by the state, private and foreign nationals. The bank capitalisation appears as the most significant variable that can contribute to the explanation of risk bearing of banks in the zone. Nevertheless, 
future studies will increase knowledge on the behaviour of managers of the banks in the zone if other variables such as the remuneration of managers and interactions between the different variables of governance and the ownership structure were taken into account.

\section{References}

Adams, R., \& Mehran, H. (2003, May). Board structure, banking firm performance and the Bank Holding Company organizational form. Federal Reserve Bank of Chicago Proceedings, 408-422.

Adams, R., \& Mehran, H. (2008). Corporate performance, board structure and its determinants in the banking industry. Federal Reserve Bank of New York, Staff Reports No. 330.

Aggarwal, R., \& Jacques, K. (1998). Assessing the Impact of Prompt Corrective Action on Bank Capital and Risk. Economic Policy Review, Federal Reserve Bank of New York. http://dx.doi.org/10.2139/ssrn.1024839

Alexandre, H., \& Paquerot, M. (2000, Juin). Efficacité des Structures de Contrôle et Enracinement des Dirigeants. Finance Contrôle Stratégie, 3(2), 5-29.

Avom, D., \& Eyeffa, Ekomo S. M. L. (2007). Quinze ans de restructuration bancaire dans la CEMAC: qu'avons-nous appris?. Revue d'économie financière, (189), 1-24.

Bainbridge, S.N. (2002). Director V. Shareholder Primacy in the Convergence Debate. Working Paper, UCLA.

Bassem, S., \& Boujelbene, Y. (2012). Effect the internal banking mechanism of governance on the risk-taking by the Tunisian banks. International Journal of economics, Financial and Management, I(1).

Bell, J., \& Pain, D. (2000). Leading Indicator Models of Banking Crises: A Critical Review. Financial Stability Review, Bank of England.

Berger, A., Clarke, G., Cull, R., Udell, G., \& Klapper, L. (2005). Corporate governance and bank performance: A joint analysis of the static, selection, and dynamic effects of domestic, foreign, and state ownership. Journal of Banking and Finance, 29, 2179-2221. http://dx.doi.org/10.1016/j.jbankfin.2005.03.013

Berle, A., \& Means, G. (1932). The Modern Corporation and Private Property. Macmillan Books, New York.

Blanchard, D., \& Dionne, G. (2004). The Case for Independent Risk Management Committees. Risk, 17(5), S19-S21.

Bonin, J., Hasan, I., \& Wachtel, P. (2005). Bank performance, efficiency and ownership in transition countries. Journal of Banking and Finance, 29, 31-54. http://dx.doi.org/10.1016/j.jbankfin.2004.06.015

Boubel, A., \& Pansard, F. (2004). Les investisseurs institutionnels, Repères. Editions La Découverte.

Bourbonnais, R. (2011). Econométrie, Dunod 8e édition. p. 379.

Boussasa, R. (2012). L'impact de la gouvernance bancaire et de la relation bancaire sur le risque de crédit: cas des banques tunisiennes. Thèse de Doctorat, Université Montesquieu- Bordeaux IV.

Brewer, E., Jackson, W., \& Jagtiani, J.A. (2000). Impact of independent directors and the regulatory environment on bank merger prices: Evidence from takeover activity in the 1990s. Emerging Issues Series, Supervision and Regulation Department, Federal Reserve Bank of Chicago, No. 12, December.

Bushee, B.J. (1998). The influence of institutional investors on myopic R\&D investment behaviour. Accounting Review, 73, 305-333.

Cebenoyan, A.S., Cooperman, E.S., \& Register, C.A. (1999). Ownership Structure, Charter Value, and Risk-Taking Behavior for Thrifts. Financial Management, 28, 43-60. http://dx.doi.org/10.2307/3666116

Claessens, S., Demirguc-Kunt, A., \& Huizinga, H. (2001). How does foreign entry affect the domestic banking market?. Journal of Banking and Finance, 25, 891-911. http://dx.doi.org/10.1016/S0378-4266(00)00102-3

Dalton, D., Daily C., Ellstrand, A., \& Johnson, J. (1999). Number of directors and financial performance: A meta-analysis. Academy of Management Journal, 42, 674-686. http://dx.doi.org/10.2307/256988

Demirguc-Kunt, A., \& Huizinga, H. (2004). Market discipline and deposit insurance. Journal of Monetary Economics, 51, 375-399. http://dx.doi.org/10.1016/j.jmoneco.2003.04.001

Demsetz, H. (1983). The structure of ownership and the theory of the firm. Journal of Law and Economics, (26), 375-390. http://dx.doi.org/10.1086/467041

Dinç, I.S. (2005, August). Politicians and banks: political influences on government-owned banks in emerging market. Journal of Financial Economics, 77(2), 453-479. http://dx.doi.org/10.1016/j.jfineco.2004.06.011 
Domanski, D. (2005). Foreign banks in emerging markets economies: changing players, changing issues. BIS Quaterly Review, 69-81.

Drucker, P.E. (1986). To end the raiding roulette game. Across the Board, 25(3), 30-39.

Ehrlich, I., Gallais-Hamonno, G., \& Lutter, R. (1990). Performances comparées des entreprises publiques et privées: l'exemple des grandes compagnies aériennes. document de recherche, Institut Orléanais de Finance.

Fama, E., \& Jensen, M. (1983). Agency problems and residual claims. Journal of Law and Economics, 26, 327-349. http://dx.doi.org/10.1086/467038

Gary, S. W., \& Gleason, A. (1999). Board structure, ownership and financial distress in banking firms. International Review of Economics and Finance, 8(3), 281-292. http://dx.doi.org/10.1016/S1059-0560(99)00026-X

Godlewski, C.J. (2005). Information, organisation et prise de risque dans la banque. Thèse de Doctorat, Université Robert Shuman Strasbourg III.

Graves, S.B. (1988). Institutional ownership and corporate R\&D in the computer industry. Academy of Management Journal, 31, 417-428. http://dx.doi.org/10.2307/256557

Greuning, H.V., \& Bratanovic, S. B. (2004). Analyse et gestion du risque bancaire: un cadre de référence pour l'évaluation de la gouvernance d'entreprise et du risque financier. Traduction de Rozenbaum M., Edition Eska, Paris, p. 384.

Griffith, J.M., \& Fogelberg, L. (2000). Control and bank performance. Journal of Financial and Strategic Decisions, 13(3), 63-69.

Hermalin, B. E., \& Weisbach, M. S. (2003, Avril). Boards of Directors as an Endogenously Determined Institution: A Survey of the Economic Literature. Federal Reserve Bank of New York, Economic Policy Review, 9(1), 7-26.

Hugon, P. (2007). Rentabilité du secteur bancaire et défaillance du financement du développement, le cas de la CEMAC. Revue Tiers Monde, (192), 771-788. http://dx.doi.org/10.3917/rtm.192.0771

Iannota, G., Giacomo, N., \& Sironi, A. (2007). Ownership Structure, Risk and Performance in the European Banking Industry. Journal of Banking and Finance, 31, 2127-2149. http://dx.doi.org/10.1016/j.jbankfin.2006.07.013

Jensen, M. (1993). The modern industrial revolution, exit, and the failure of internal control systems. Journal of Finance, 48, 831-880. http://dx.doi.org/10.1111/j.1540-6261.1993.tb04022.x

John, K., Saunders, A., \& Senbet, L. (2000). A Theory of Bank Regulation and Management Compensation. Review of Financial Studies, 13, 95-125. http://dx.doi.org/10.1093/rfs/13.1.95

Lipton, M., \& Lorsch, J. (1992). A modest proposal for improved corporate governance. Business Lawyer, 59, 59-77.

Louzis, D. P., Vouldis, A. T., \& Metaxas, V. L. (2012). Macroeconomic and bank-specific determinants of non-performing loans in Greece: A comparative study of mortgage, business and consumer loan portfolios. Journal of Banking and Finance, 36, 1012-1027. http://dx.doi.org/10.1016/j.jbankfin.2011.10.012

Mamoghli, C., \& Dhouibi, R. (2009). Bank Corporate Governance and Insolvency Risk Evidence from an Emerging Market. Working Paper, p. 32.

Marco, T.G., \& Fernandez, D.R (2007). Risk taking behaviour and ownership in the banking industry: the Spanish evidence. Journal of Economics and Business, 1-23.

Mc Allister, P.H., \& Mc Manus, D. (1993). Resolving the Scale Efficiency Puzzle in Banking. Journal of Banking and Finance, 17, 389-405. http://dx.doi.org/10.1016/0378-4266(93)90039-G

Mc Connell, J.J., \& Servaes, H. (1995). Equity Ownership and the two faces of debt. Journal of Financial Economics, 39, 131-157. http://dx.doi.org/10.1016/0304-405X(95)00824-X

Micco, A., Ugo, P., \& Monica, Y. (2007). Bank ownership and performance: Does politics matter?. Journal of Banking and Finance, 31, 219-241. http://dx.doi.org/10.1016/j.jbankfin.2006.02.007

Morck, R., Shleifer, A., \& Vishny, R. (1988). Management ownership and market valuation: An empirical analysis. Journal of Financial Economics, 20, 293-315. http://dx.doi.org/10.1016/0304-405X(88)90048-7

Pantalone, C., \& Platt, M. (1987). Predicting Commercial Bank Failures since Deregulation. New England Economic Review, 37-47. 
Paquerot, M. (1997). Stratégies d'enracinement des dirigeants, Performance de la Firme et Structures de Contrôle. In G. Charreaux (Ed.), Le Gouvernement des Entreprises (pp.105-138). Ed Economica.

Pathan, S. (2009). Strong boards, CEO power and bank risk-taking. Journal of Banking and Finance, 33, 1340-1350. http://dx.doi.org/10.1016/j.jbankfin.2009.02.001

Pi, L., \& Timme, S.G. (1993). Corporate control and bank efficiency. Journal of Banking and Finance, 17, 515-530. http://dx.doi.org/10.1016/0378-4266(93)90050-N

Porter, M.E. (1992). Capital disadvantage: America's Failing Capital Investment System. Harvard Business Review, 76, 65-82.

Prowse, S. (1997). Corporate control in commercial banks. Journal of Financial Research, 20, 509-527. http://dx.doi.org/10.1111/j.1475-6803.1997.tb00263.x

Saunders, A., Strock, E., \& Travelos, N. (1990). Ownership, Deregulation, and Bank Risk Taking. Journal of Finance, 45, 643-654. http://dx.doi.org/10.1111/j.1540-6261.1990.tb03709.x

Shleifer, A. (1998). State versus private ownership. Journal of Economic Perspectives, 12, 133-150. http://dx.doi.org/10.1257/jep.12.4.133

Shleifer, A., \& Vishny, R. (1997). A survey of corporate governance. Journal of Finance, 52, 737-783. http://dx.doi.org/10.1111/j.1540-6261.1997.tb04820.x

Shrieves, E., \& Dahl, D. (1992). The relationship between risk and capital in commercial banks. Journal of Banking and Finance, 16, 439-457. http://dx.doi.org/10.1016/0378-4266(92)90024-T

Sironi, A., Iannota, G., \& Giacomo, N. (2006). Ownership Structure, Risk and Performance in the European Banking Industry. Journal of Banking and Finance.

Stiglizt, J., \& Weiss, A. (1981). Credit rationing in markets with imperfect information. American Economic Review, 71(3), 393-410. http://dx.doi.org/10.1016/S0929-1199(00)00005-5

Thierno, B. A. (2007). Structure actionnariale des banques, risques et efficience. Thèse de Doctorat, Université de Limoges.

Verdier, E., \& Hodonou, D. (2010). Mécanismes internes de gouvernance et performances financière: le cas des banques de la zone UEMOA. Revue française de gouvernance, (7).

Von Westernhagen, N., Harada, E., Nagata, T., Vale, B., Ayuso, J., Saurina, J., ... Peristiani, S. (2004). Bank Failures in Mature Economies. Discussion paper, Basel Committee on Banking Supervision, Bank for International Settlements (BIS).

Wahal, S., \& MC Connell, J.J. (2000). Do institutional investors exacerbate managerial myopia?. Journal of corporate Finance, (6), 307-329.

Whidbee, D.A. (1997). Board composition and control of shareholder voting rights in the banking industry. Financial Management, 26(4), hiver, 27-41. http://dx.doi.org/10.2307/3666125

\section{Notes}

Note 1. The Community of West African States.

Note 2. The Economic and Monetary Community of Central African States.

Note 3. These authors refer to the internal committee, that can be of two types; those oriented towards the improvement of productivity (financing, investment and strategic questions) that encourage, evaluate and ratify long term decisions; and those oriented towards the control of managers (audits, remuneration and nomination).

Note 4. The banking Commission of Central African states.

Note 5. Several studies try to demonstrate that the excess liquidity of the banking system in the CEMAC region, such as Fouda, 2009 and Beguy 2010, and the stock exchange being at an embryonic stage, market risk does not exist.

Note 6. It is also the risk of accounting failure.

Note 7. According to the findings of Vernier and Hodonou (2010).

Note 8. European Banking Federation (2011). 